\title{
Reign of Appearances: The Misery and Splendor of the Public Sphere
}

\author{
Cambridge University Press, New York, 2018., 220 str.
}

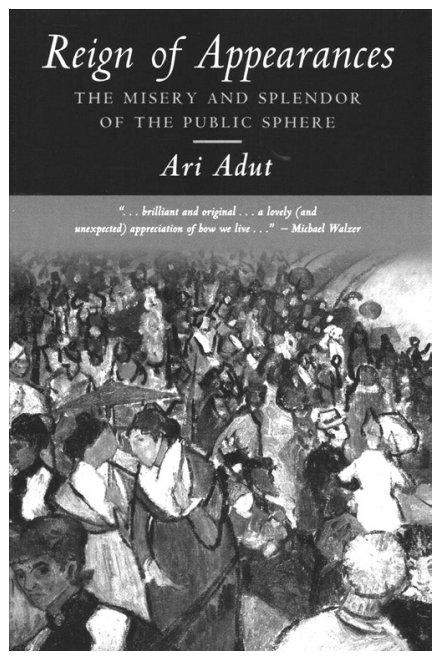

Reign of Appearances: The Misery and Splendor of the Public Sphere novo je djelo autora Arija Aduta, koje doživljava svoje izdanje skoro desetljeće nakon Adutove prve knjige On Scandal: Moral Disturbances in Society, Politics and Art (Structural Analysis in the Social Sciences). Ari Adut profesor je sociologije na Sveučilištu u Texasu, a u područje istraživačkoga interesa ubraja, između ostalog, komparativnu sociologiju, sociologiju kulture, političku sociologiju te odnos medija i javne sfere. Vremenski moment izdavanja ove knjige nije manje važan jer autor pomoću provokativnih primjera iz javne sfere objašnjava odnos društvene i političke dinamike, o čemu svjedoči analiza afera Dreyfus, Watergate i Lewinsky, osvrt na homoseksualnost u viktorijanskoj Engleskoj i slučaj Oscara Wildea, opisi početaka antisemitizma u Europi, borbe pijetlova na Baliju, nasilja tijekom Francuske revolucije, suvremene seksualne politike te američkih izbora 2016. godine. Neki od koncepata koje autor definira u knjizi asimetrija je u djelovanju aktera javne sfere, uloga spektakla i publiciteta te djelovanje političkih aktera pomoću cenzure, ali i pomoću sve većeg otkrivanja detalja o sebi i svom radu. Glavni je fokus analize gledateljstvo ili publika, odnosno ona većina građana koji najčešće sudjeluju u javnoj sferi na način da promatraju košnicu događanja kojom orkestriraju politički i civilni aktivisti, mediji, zakonodavstvo i društvene norme. Element koji povezuje grčku agoru i naslovnicu New York Timesa je vidljivost, a, bila ona fizička ili virtualna, vidljivost je bitna za razumijevanje moći i identiteta u liberalnoj demokraciji.

U prvome poglavlju pod nazivom „Kritika“ autor polazi od kritike Habermasove definicije javne sfere, prema kojoj je javna sfera koncept u kojemu se oblikuje javno mišljenje i koji je otvoren za dijalog svih građana. Adut to općeprihvaćeno shvaćanje javne sfere naziva „konvencionalna perspektiva“, u kojoj razlikuje tri problematična elementa. Prvi je element građanski angažman. Prema konvencionalnoj perspektivi postoji jasna veza između javne sfere i normativne orijentacije građana koji u njoj sudjeluju te se smatra da je zajedničko dobro raison d'être javne sfere. Autor tvrdi da 
u događanjima u javnoj sferi postoji asimetrija između onih koji su za govornicom i onih koji su došli samo slušati, a njihove argumente teško možemo razlikovati od standardne ideologije. Drugi je element građanstvo. Naivno se vjeruje da su djelovanje civilnoga građanstva za opće dobro svih i političko djelovanje odvojeni jedno od drugog. Oboje su dio kolektiva koji profitira od veza s političkim strankama, dok se razlikuju po tome što su ovi prvi akteri označeni kao romantistički, a ovi drugi kao beskrupulozni i gladni moći. Treći je element egalitarna i široko rasprostranjena participacija. Javna komunikacija rijetko će se razviti u formi egalitarnoga dijaloga. Politička indiferentnost i letargija široko su rasprostranjene u vremenu i prostoru upravo zbog spomenute asimetrije između manjine koja govori i djeluje te većine koja gleda i sluša.

Poglavlje „Realistična perspektiva“ započinje tvrdnjom kako konvencionalna perspektiva često ne uzima u obzir prostor javne sfere, bilo da se radi o stvarnome bilo o virtualnome prostoru. Autor razlikuje tri različita pristupa prostoru javne sfere: fizički, reprezentativni i osjetilni. U skladu s tim prostor je javne sfere općenito govoreći prostor koji je vidljiv i koji ima svoju publiku. Adut isto tako pravi razliku između privatne i javne sfere. Privatna je sfera mjesto koje je zakonskim i društvenim normama zaštićeno od općega nadzora, a javna sfera nije zaštićena od osjetilnoga pristupa u općem smislu. Za javnu je sferu karakteristično objektiviziranje fokusa, dok je dijalog inherentno privatni fenomen koji podrazumijeva bliskost i povjerenje. Nadalje, postoje tri razine vidljivosti u javnoj sferi: biti dostupan općem pogledu, biti zamijećen i biti u fokusu gledateljstva. Budući pak da je vanjština važan element javne sfere, osobe i predmeti u javnoj sferi predmet su moralne i estetske prosudbe.

Nakon toga autor uvodi pojam publiciteta, obrazlažući kako je upravo publicitet najviša razina vidljivosti te je usko povezan s centralnim javnim mjestima. K tomu, opće je znanje superiorno pluralističkom neznanju, a publicitet može generirati opće znanje. Ono što se nalazi u javnoj sferi dobit će puno više pažnje ako ima publicitet. Štoviše, publicitet može imati i kolektivne efekte na način da izolirane pojedince pretvori u solidarizirane grupe ako su oni fokusirani na istu stvar. Međutim, u slučaju da taj fokus grupi predstavlja represivni element i tenzije, publicitet može oslabiti grupu. Isto tako publicitet može utjecati i na društveni status. Zahvaljujući tome što publicitet pojačava fokus pojedinci mogu dosegnuti mitske visine. S druge strane, ponašanje toga pojedinca tada ovisi o očekivanjima publike, a publicitet može taj glorificirani predmet fokusa preokrenuti u laku metu za napad i kritiku.

Četvrto poglavlje Adut posvećuje politici u javnoj sferi. Svi politički akteri koji imaju bilo kakvu moć odlučivanja u društvu koriste publicitet kako bi promovirali sebe i svoj rad. Kad se političar primjerice uspoređuje sa svojim protivnikom, predstavlja se kao usamljeni David u borbi protiv Golijata. Obični građani samo su gledatelji toga spektakla, a njihovo političko djelovanje svodi se na privatan čin glasovanja. Doduše, u vrijeme tehnoloških inovacija i korištenja društvenih mreža publicitet može biti dvostruki mač za političare jer više ne mogu segregirati svoju publiku i reći različite stvari različitim grupama. Iako je pojam ,javna autentičnost“ oksimoron, političari često koriste koncept autentičnosti kako bi se prikazali kao „idealistični autsajderi koji su dio antiinstitucionaloga etosa“ (Adut, 2018.:77). Važan dio semiotike javne sfere i strateška je upotreba skandala u političkome djelovanju, gdje se pomoću publiciteta iznose određene stvari koje nisu u skladu s protivnikovim javnim statusom: 
skriveni novac, sebični interesi, poduzetnički apetiti. Vidljivost u liberalnoj demokraciji nedvojbeno ima pozitivan efekt jer su na taj način politički akteri i institucije odgovorni za svoj rad. S druge strane, vidljivost može voditi sve većem diskreditiranju rada političkih institucija, što može narušiti povjerenje u njih i naposljetku oslabiti društvo u cjelini jer je određena količina povjerenja u političke institucije javno dobro. Osim toga vidljivost ima ambivalentan utjecaj i na građanstvo. Posve je razumljivo da je pristup javnoj sferi i protoku informacija važan za građanstvo liberalne demokracije. Međutim građanstvo koje je prekomjerno ispolitizirano znak je disfunkcionalne politike države. K tomu, što je politički život građana više izložen javnosti, to će manjine više biti u strahu od tiranije većine jer je odlika autoritativnih vlada građanstvo koje ne glasa privatno nego javno.

Peto poglavlje, „Regulacija sadržaja“, bavi se dijalektičkom vezom moći i javne sfere. Politički akteri koriste cenzuru kako bi kontrolirali sadržaje u javnoj sferi. U tehničkome se smislu cenzura odnosi na govor, tekstove, slike i ostalu semiološku građu. Može biti korisna kada se odnosi na zaštitu određene publike kao što su maloljetnici ili različite religijske zajednice. Međutim može biti i sredstvo kontrole vidljivosti, pri čemu javna sfera postaje predmetom političke aktivnosti. Tu autor isto tako naglašava da društveni znanstvenici nisu dovoljno precizno odredili razliku između tabua i društvenih zabrana jer samo jedno iskustvo tabua može nepovoljno utjecati na pojedinčevu osjetilnu percepciju, a tabu je per se povezan s publicitetom. Adut dalje pravi razliku između ekspanzije i sažimanja u javnoj sferi. Ekspanzija se javlja kad ponavljanjem određenih skandala bez izricanja kazne i negativnih reakcija oni postaju normalan sadržaj u društvu. U procesu sažimanja određeni sadržaji postaju nepoželjni u javnoj sferi, a uzrok mogu biti procesi modernizacije i civilizacije.

U šestom pak poglavlju, „Vidljivost u društvu“, Adut profilira vidljivosti u društvu koje mogu diskriminacijski utjecati na pojedinca i grupu. Vidljivost društvenih grupa može im nedvojbeno osigurati različite prednosti, osnažiti samouvjerenost i identitet. U relacijskoj konstrukciji društvenih identiteta superiorna grupa označava subordinativnu grupu kao „drugu“ i zapravo ne traži priznanje od subordinativne grupe, nego od onih koji su također superiorni. Međutim prevelika vidljivost kolektiva kao što je obitelj, religijska zajednica ili organizacija može utjecati na njegov integritet i dovesti u opasnost solidarnost među članovima. Takav kolektiv može biti autonoman samo ako postoji povjerenje, disciplina i unitaristički identitet. U zadnjem dijelu ovoga poglavlja autor se osvrće na Foucaultovo razmišljanje o konceptu Panopticona i o ludilu. Dio posvećen Panopticonu i horizontalnom i vertikalnom nadzoru pomalo je proturječan u svojoj analizi. Adut smatra da Panopticon, Benthamov model zatvora u kojem su zatvorenici vidljivi dok stražari nisu, nije održiv. U prvome redu nijedan takav zatvor nije izgrađen, a održavanje takvih zatvora bilo bi zahtjevno financijski. S druge strane, moderna politička moć funkcionira na način da je vidljiva kroz medije, odnosno politički akteri nisu nikad prije u povijesti bili izloženi ovakvoj vidljivosti. Isto tako većina istraživanja o nadzoru koja se vodi Foucaultovom teorijom ne pravi razliku između vertikalnoga i horizontalnoga nadzora. U modernim društvima smanjen je horizontalni nadzor, a povećan vertikalni, što otprilike znači da više nismo pod budnim okom susjeda, ali vlada i Google imaju pristup našim financijskim transakcijama i emailovima. Naposljetku Adut uvodi Foucaultov opis ludila. Foucault drži da je prije modernih vremena granica između ludila i razuma 
bila tanka, te se ludilo čak izjednačavalo s mudrošću. Međutim modernost je ludilo označila kao bolest i takve pojedince maknula iz vidljivosti u društvu i dala im vertikalnu vidljivost u zatvorenim institucionalnim prostorima. Adut smatra da je takav nostalgični opis predmodernoga vremena netočan jer je upravo pojava moderne psihijatrije dala takvim ljudima humano iskustvo. Do tada su oni služili kao savršen spektakl i atrakcija za gledatelje, što znači da to za njih nije bilo osnažujuće iskustvo, nego ih je činilo ranjivima.

Sedmo poglavlje donosi pregled pravnih i moralnih dvoznačnosti u javnoj sferi. Velika vidljivost sudskih postupaka može pomoću publiciteta pretvoriti pravni postupak u popularni pravni postupak. U tom slučaju vrijednosti i očekivanja publike mogu utjecati na trajanje postupka i djelovanje sudskih aktera, a potonji će također više brige voditi o svom nastupu i pojavi ispred publike. Napokon, javna je sfera neautentična, a većina je moralnih kvaliteta koje se pokazuju u javnoj sferi upitna. Integritet privatnih komunikacija i stvari ugrožen je onoga trenutka kad postane javan i vidljiv svima. S druge strane, javna sfera bogata je pojavama i površnostima koje joj daju neku vrstu moralnoga poretka. Ako uzmemo u obzir da su pojave u javnoj sferi samo reprezentacije njih samih u odnosu na druge, onda nam one mogu poslužiti da se bolje odnosimo prema drugim pojedincima, na primjer upotreba manira u formalnome okruženju.

Posljednje poglavlje predstavlja autorovu obranu uloge gledateljstva i publike u javnoj sferi. Polazi od činjenice da većina društvenih znanosti naglašava ulogu interakcije u javnoj sferi koja vodi građanskoj participaciji. Adut smatra da će u javnoj sferi umjesto dijaloga uvijek biti prisutna asimetrija između predstavnika i onih koje oni predstavljaju, odnosno gledateljstva. S obzirom na to Adut gledateljstvo uspoređuje s francuskim pojmom flâneur, tj. prolaznik ili šetač, koji označava onoga koji je inspiriran znatiželjom dok prolazi vrevom bogatoga gradskog života. Za razliku od autentičnoga flâneura, oni koji aktivno sudjeluju u javnoj sferi i predmet su gledanja flâneura inspirirani su doxom, slavom i mišljenjem drugih. U antičkoj Grčkoj theoros je bio onaj koji je putovao kako bi promatrao svijet i na temelju toga svoja razmišljanja sažeo u theoriu.

Možemo zaključiti da teme obrađene u ovoj knjizi posjeduju određenu svevremenost jer komentiranje veza između kulturnih i političkih događanja posjeduje i senzacionalistički i intelektualni potencijal. Javna će sfera uvijek biti pomodna fraza pomoću koje će se nastojati objasniti fenomeni u društvu, bilo da se radi o fizičkim prostorima kao što su gradski trgovi i ulice bilo o virtualnom prostoru kao što je internet. Na temelju toga proizlazi da je knjiga namijenjena svima koji drže interesantnim povezivanje sociološke, filozofske, antropološke i semantičke teorije $s$ primjerima iz povijesti umjetnosti, ali i naslovnica žutoga tiska, što Adut čini sa sofisticiranom lakoćom. 